\title{
Effects of trans-endocardial delivery of bone marrow-derived CD133+ cells on angina and quality of life in patients with refractory angina: A sub-analysis of the REGENT-VSEL trial
}

Tomasz Jadczyk ${ }^{1}$, Joanna Ciosek $^{1}$, Aleksandra Michalewska-Wludarczyk ${ }^{1}$, Wojciech Szot ${ }^{2}$, Zofia Parma ${ }^{1}$, Beata Ochala ${ }^{1}$, Miroslaw Markiewicz ${ }^{3}$, Wojciech Rychlik ${ }^{4}$, Magdalena Kostkiewicz ${ }^{5}$, Katarzyna Gruszczynska ${ }^{6}$, Anna Blach ${ }^{1}$, Monika Dzierzak-Mietla ${ }^{3}$, Lukasz Rzeszutko ${ }^{7}$, Lukasz Partyka ${ }^{8,9}$, Wojciech Zasada ${ }^{7,8}$, Grzegorz Smolka ${ }^{1}$, Tomasz Pawlowski ${ }^{1}$, Marek Jedrzejek ${ }^{1}, Z_{\text {denek Starek }}{ }^{10,11}$, Krzysztof Plens ${ }^{8}$, Andrzej Ochala ${ }^{1}$, Michal Tendera ${ }^{1}$, Wojciech Wojakowski ${ }^{1}$

${ }^{1}$ Division of Cardiology and Structural Heart Diseases, Medical University of Silesia, Katowice, Poland; ${ }^{2}$ Hygiene and Dietary Department, Jagiellonian University, Collegium Medicum; Department of Nuclear

Medicine, Hospital John Paul II, Krakow, Poland; ${ }^{3}$ Department of Hematology and Bone Marrow Transplantation, Medical University of Silesia, Katowice, Poland; ${ }^{4}$ Department of Anaesthesiology and Intensive Care with Cardiac Monitoring, Upper Silesian Medical Center, Katowice, Poland;

${ }^{5}$ Department of Cardiovascular Diseases, Jagiellonian University, Hospital John Paul II, Krakow, Poland;

${ }^{6}$ Division of Diagnostic Imaging, Medical University of Silesia, Katowice, Poland; ${ }^{7} 2^{\text {nd }}$ Department of Cardiology and Cardiovascular Interventions, University Hospital, Krakow, Poland; ${ }^{8}$ Krakow Cardiovascular Research Institute, Krakow, Poland; ${ }^{9}$ Department of Angiology, University Hospital, Krakow, Poland;

${ }^{10}$ International Clinical Research Centre, St. Anne's University Hospital Brno, Czech Republic;

${ }^{11}$ Masaryk University, Faculty of Medicine, Brno, Czech Republic

\begin{abstract}
Background: The REGENT-VSEL trial demonstrated a neutral effect of transendocardial injection of autologous bone marrow (BM)-derived CD133+ in regard to myocardial ischemia. The current sub-analysis of the REGENT-VSEL trial aims to assess the effect stem cell therapy has on quality of life $(Q o L)$ in patients with refractory angina.

Methods: Thirty-one patients (63.0 \pm 6.4 years, $70 \%$ male) with recurrent CCS II-IV angina, despite optimal medical therapy, enrolled in the REGENT-VSEL single center, randomized, double-blinded, and placebo-controlled trial. Of the 31 patients, 16 individuals were randomly assigned to the active stem cell group and 15 individuals were randomly assigned to the placebo group on a 1:1 basis. The inducibility of ischemia, ( $\geq$ one myocardial segment) was confirmed for each patient using Tc-99m SPECT. QoL was measured using the Seattle Angina Questionnaire. Each patient completed the questionnaire prior to treatment and at the time of their outpatient follow-up visits at 1, 4, 6, and 12 months after cell/placebo treatment.
\end{abstract}

Results: The main finding of the REGENT-VSEL trial sub-analysis was that transendocardial injection of autologous BM-derived CD133+ stem cells in patients with chronic refractory angina did

Address for correspondence: Wojciech Wojakowski, MD, PhD, Division of Cardiology and Structural Heat Diseases, Medical University of Silesia, ul. Ziołowa 45-47, 40-635 Katowice, Poland, tel/fax: +48 3225239 30, e-mail: wwojakowski@sum.edu.pl

Received: 23.06.2018 Accepted: 08.08.2018 
not show significant improvement in QoL in comparison to the control group. Moreover, there was no significant difference between cell therapy and placebo in a number of patients showing improvement of at least 1 Canadian Cardiovascular Society class during the follow-up period.

Conclusions: Intra-myocardial delivery of autologous CD133+ stem cells is safe and feasible but does not show a significant improvement in the QoL or angina pectoris symptoms in patients with chronic myocardial ischemia. (Cardiol J 2018; 25, 4: 521-529)

Key words: quality of life, refractory angina, bone marrow, cell therapy, CD133 cells

\section{Introduction}

Advances in the surgical, interventional and pharmacological treatment of patients with acute coronary syndromes have improved long-term clinical outcomes including quality of life (QoL). Moreover, novel therapeutic strategies are beneficial for patients with stable coronary artery disease (CAD) and large myocardial ischemic burden [1-3]. Nevertheless, as a consequence of an aging population, the number of individuals with severe coronary atherosclerosis not amendable for conventional revascularization continues to increase [4]. In many patients, despite optimal medical therapy, chronic myocardial ischemia is associated with debilitating anginal pain, which adversely influences QoL. Persistent ischemic chest discomfort is related to a higher rehospitalization rate [5], mortality and morbidity [6, 7]. Transendocardial delivery of autologous and allogeneic stem/ progenitor cells is a promising alternative treatment option for patients diagnosed with refractory angina. Noteworthly, Rodrigo et al. [8] have also indicated an important economic aspect that this therapy is proving to reduce system resources of healthcare utilization. However, previously published data showed inconsistent results in regard to stem cell effectiveness. Studies with unselected mononuclear cells demonstrated a beneficial impact on angina symptoms and improvement of myocardial perfusion [9-11]. Conversely, the PROGENITOR trial enrolling refractory angina patients, who underwent transendocardial CD133+ cells injection, did not confirm previous observations [12]. Thus, additional studies are needed to evaluate and establish an optimal treatment strategy. In addition, factors such as patient selection criteria, cell types and route of administration should all be taken into consideration.

In the present study, QoL and the severity of chest pain in no-option angina patients treated with transendocardial autologous bone marrow-derived CD133+ cells were evaluated as the REGENT-VSEL trial sub-analysis (NCT01660581, www. clinicaltrials.gov) [13].

\section{Methods}

REGENT-VSEL, a single center, randomized, double-blinded, placebo-controlled study, was coordinated by an independent Clinical Research Organization (www.kcri.pl), which provided a randomization system using sealed envelopes. Randomization was performed in the hematology center before cell/placebo processing on 1:1 basis. The study protocol and baseline characteristics are described in the previous publication [13]. Briefly, patients with refractory angina pectoris despite optimal medical therapy and were disqualified from further revascularization procedures were enrolled in the study.

\section{Inclusion criteria}

Inclusion criteria were as follows: 1) stable angina in Canadian Cardiovascular Society (CCS) II-IV class despite maximum pharmacotherapy for at least 2 weeks since the prior medication change; 2) presence of $\geq 1$ myocardial segment with reversible ischemia in qualifying Tc-99m single photon emission computed tomography (SPECT); 3) disqualified from further revascularization by an independent Heart Team; 4) age $>18$ and $<75$ years and 5) written informed consent.

\section{Exclusion criteria}

Exclusion criteria were as follows: 1) acute coronary syndrome $\leq 6$ months; 2 ) heart failure New York Heart Association (NYHA) III-IV class; 3) left ventricular (LV) ejection fraction (LVEF) $<35 \%$; 4) contraindications to NOGA procedure (ventricular wall thickness $<8 \mathrm{~mm}$, intracardiac thrombus, severe aortic stenosis, LV an aneurysm or severe peripheral artery disease precluding vascular access); 5) previous implantation of cardioverter-defibrillator or pacemaker; 6 ) history of malignancy; 7) active infection; 8) life expectancy less than 6 months; 9) bleeding diathesis; 10) renal insufficiency (GFR $<30 \mathrm{~mL} / \mathrm{min} / 1.73 \mathrm{~m}^{2}$ ) and 11) pregnancy, lactation, or lack of adequate contraception in women of childbearing potential. After 
providing informed consent patients underwent baseline SPECT and magnetic resonance imaging.

\section{End-points}

Based on the REGENT-VSEL trial, the following end-points were evaluated in this sub-analysis: QoL and change in the angina severity (CCS class) assessed at baseline and during outpatient followup visits at $1,4,6,12$ months after cell/placebo application.

\section{Endocardial mapping and intramyocardial injection}

NOGA-XP 3D electro-mechanical system (Biosense Webster, Johnson\&Johnson, Diamond Bar, CA, USA) was applied for endocardial mapping (200-250 valid points collected) and intramyocardial application. In the active group, patients received autologous $\mathrm{CD} 133+$ bone marrow (BM)-derived stem cells (mean number of $3.2 \pm 2.4 \times 10^{6}$ ). In the placebo group, patients received $0.9 \% \mathrm{NaCl}$ with the addition of $10 \%$ donor serum. The region of interest was determined based on NOGA-XP electromechanical parameters defining hibernating areas (an abnormal mechanical function with viable myocardium). A median of 10 trans-endocardial cell/placebo injections (200 $\mu \mathrm{L}$ per application) were performed with a comparable mean volume in both groups.

\section{Clinical status and QoL assessment}

During hospitalization and scheduled outpatient follow-up visits at $1,4,6,12$ months after cell/placebo delivery: (1) severity of angina was assessed according to the CCS scoring system, grading chest pain symptoms from I to IV and (2) QoL as measured using the Seattle Angina Questionnaire (SAQ) ranging from $0 \%$ to $100 \%$ [14]. The SAQ quantifies five categories: physical limitation (PL), angina stability (AS), angina frequency (AF), treatment satisfaction (TS) and quality of life score (QOLs).

Participant treatment allocations were double-blinded during hospitalization and during the whole follow-up period. Moreover, the principal investigator was blinded in regard to QoL questionnaires filled out by patients during outpatient clinic visits.

The REGENT-VSEL study was approved by the Ethics Committee of the Medical University of Silesia in Katowice and Office for Registration of Medicinal Products, Medical Devices, and Biocidal Products. The trial is in accordance with the Declaration of Helsinki.

\section{Statistical analysis}

Categorical variables were presented as numbers and percentages. Continuous variables were expressed as the mean \pm standard deviation (SD) or median and interquartile range (IQR). Differences between groups were compared using the Student or Welch t-test depending on equality of variances for normally distributed variables. The Mann-Whitney U test was used for non-normally distributed continuous variables and ordinal data. The Shapiro-Wilk test assessed normal distribution of variables. Equality of variances was assessed using the Levene test. $\mathrm{P}$ values $<0.05$ were considered statistically significant. All calculations were done with JMP ${ }^{\circledast}$, Version 13.1.0 SAS Institute Inc., Cary, NC.

\section{Results}

Out of 90 patients screened, 31 individuals $(63.0 \pm 6.4$ years, $70 \%$ male) were enrolled in the study and were randomly assigned to an active treatment group receiving CD133+ cells $(\mathrm{n}=16)$ or placebo group $(n=15)$. There were no significant differences in the distribution of baseline characteristics and pharmacotherapy between the study groups (Table 1 ).

The occurrence of peri-procedural serious adverse events (SAE) was noted in 2 patients allocated to the active group: (1) acute back pain in the lumbar area radiating to the abdomen during the mapping procedure, which was related to previously diagnosed spondyloarthritis and was fully resolved after analgesic treatment, (2) pseudoaneurysm of the femoral artery.

\section{Clinical parameters}

Clinical assessment was carried out at baseline and after 1, 4, 6 and 12 months in an outpatient setting.

There were no cases of death or of myocardial infarction (MI) noted during outpatient follow-up visits. Two SAEs occurred in the placebo-treated group, (unstable angina: treated medically; deep vein thrombosis) and one $\mathrm{SAE}$ in the active group which was a hospital admission for unstable angina and was treated conservatively.

Repeated measure analysis of CCS changes within groups showed no significant differences: $\mathrm{p}=0.63$ and $\mathrm{p}=0.32$ in stem cell and placebo group, respectively (Fig. 1A, B). Overall differences across the repeated measures of CCS in the total population was observed $(\mathrm{p}=0.04)$, but did not vary across study groups $(\mathrm{p}=0.38)$. 
Table 1. Baseline characteristics of study groups.

\begin{tabular}{|c|c|c|c|}
\hline & Placebo group $(\mathrm{n}=15)$ & Active group $(n=16)$ & $\mathbf{P}$ \\
\hline Age [years] & $61.7 \pm 5.4$ & $64.2 \pm 7.2$ & 0.28 \\
\hline Man & $11(73.3 \%)$ & $12(75.0 \%)$ & $>0.99$ \\
\hline \multicolumn{4}{|l|}{ Cardiovascular risk factors: } \\
\hline Smoking (current or past) & $6(40 \%)$ & $10(62.5 \%)$ & 0.29 \\
\hline Hypertension & $13(86.7 \%)$ & $15(93.7 \%)$ & 0.60 \\
\hline Diabetes & $8(53.3 \%)$ & $4(25 \%)$ & 0.15 \\
\hline Chronic kidney disease & $2(13.3 \%)$ & $1(6.2 \%)$ & 0.60 \\
\hline Dyslipidemia & $14(93.3 \%)$ & $15(93.7 \%)$ & $>0.99$ \\
\hline Family history of CAD & $5(33.3 \%)$ & $8(50 \%)$ & 0.47 \\
\hline \multicolumn{4}{|l|}{ Chronic medications: } \\
\hline ASA & $15(100 \%)$ & $16(100 \%)$ & - \\
\hline Clopidogrel & $6(40 \%)$ & $6(37.5 \%)$ & $>0.99$ \\
\hline ACEI & $12(80 \%)$ & $13(81.2 \%)$ & $>0.99$ \\
\hline ARB & $3(20 \%)$ & $3(18.7 \%)$ & $>0.99$ \\
\hline Statins & $15(100 \%)$ & $16(100 \%)$ & - \\
\hline ССВ & $7(46.7 \%)$ & $5(31.2 \%)$ & 0.47 \\
\hline Beta-blockers & $14(93.3 \%)$ & $15(93.7 \%)$ & $>0.99$ \\
\hline Nitrates & $4(26.7 \%)$ & $10(62.5 \%)$ & 0.07 \\
\hline Diuretics & $10(66.7 \%)$ & $6(37.5 \%)$ & 0.15 \\
\hline \multicolumn{4}{|l|}{ Medical history: } \\
\hline Prior myocardial infarction & $11(73.3 \%)$ & $10(62.5 \%)$ & 0.70 \\
\hline Prior CABG & $12(80 \%)$ & $13(81.2 \%)$ & $>0.99$ \\
\hline Prior $\mathrm{PCl}$ & $10(66.67 \%)$ & $12(75 \%)$ & 0.70 \\
\hline
\end{tabular}

ASA - acetylsalicylic acid; ACEI — angiotensin converting enzyme inhibitor; ARB — angiotensin II receptor blocker; CABG — coronary artery bypass grafting; CAD — coronary artery disease; $\mathrm{CCB}$ - calcium channel blockers; $\mathrm{PCl}$ — percutaneous coronary intervention

In comparison to the placebo group, QOLs improved 1 month after stem cell therapy (60.42 \pm \pm 19.12 vs. $44.44 \pm 19.84, \mathrm{p}=0.05$, respectively) However, there was no significant difference measured after 4 months $(55.36 \pm 23.02$ vs. $49.40 \pm$ $\pm 22.52, \mathrm{p}=0.81$, respectively), 6 months $(60.71 \pm$ \pm 25.20 vs. $55.45 \pm 25.08, \mathrm{p}=0.64$, respectively) and 12 months $(63.33 \pm 21.55$ vs. $53.06 \pm 21.04$, $\mathrm{p}=0.26$, respectively) (Fig. 2). Furthermore, there was a statistically significant inter-group difference in QOLs at month 1 and $4(\mathrm{p}=0.04)-$ QOLs improved in the placebo group with no change in treatment (Table 2).

One-year evaluation of PL, AS, AF and TS showed similar results between the two groups. Table 3 shows PL score measured during consecutive follow-up visits. In comparison to baseline, PL increased in both control and treatment groups throughout the first year of follow-up. A statistically significant difference was observed between month 1 and $6(\mathrm{p}=0.03)$. The PL score decreased in the treatment group but improved in the placebo group. There was no difference detected between the two groups in the AS and AF scores (Table 4 and Table 5, respectively). Analysis of TS, presented in Table 6 , showed a statistically non-significant trend towards inter-group difference between month 1 and 4 as well as between month 1 and 6 post stem cell/placebo treatment.

\section{Discussion}

In accordance with previously published studies, the REGENT-VSEL trial showed that intramyocardial application of autologous stem cells is safe and feasible [9-11, 15]. However, the main finding of the present sub-analysis is that transendocardial application of autologous BM-derived CD133+ stem cells in patients with chronic refractory angina did not show significant improvement in the QoL and CCS class within 12 month follow-up. Similarly, in the PROGENITOR trial [12] 


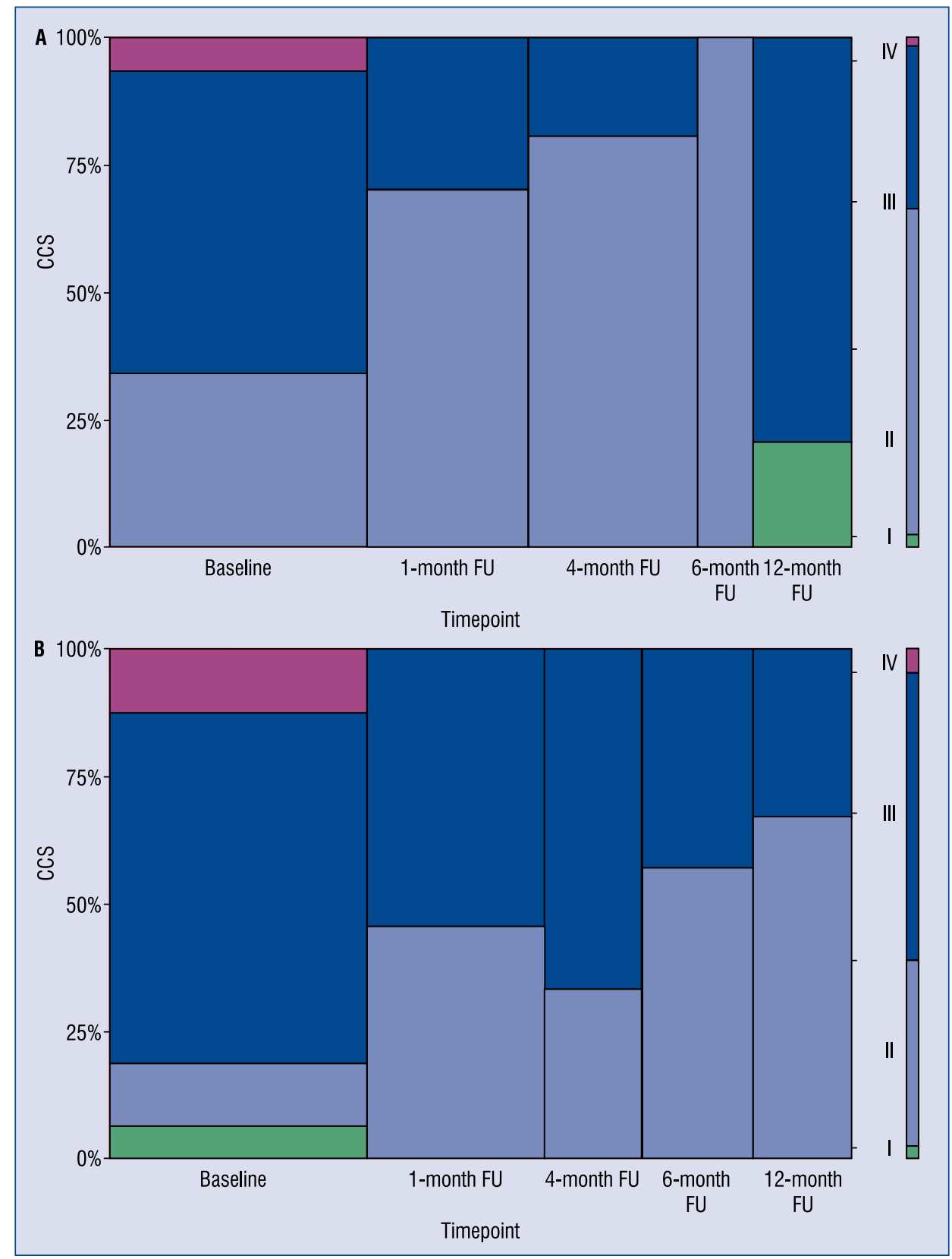

Figure 1. Mosaic plot representing Canadian Cardiovascular Society (CCS) changes during 12-month follow-up (FU) in stem cell group (A) and placebo group (B).

peripheral blood (PB)-derived immuno-selected CD133+ cells were applied showing no improvement in regard to QoL and angina symptoms. On the contrary, the ACT34-CMI [9] and RENEW [16] trials suggest the clinical applicability of intramyocardially injected $1 \times 10^{5} / 5 \times 10^{5}$ and $1 \times 10^{5}-1 \times 10^{7}$ selected CD34+ cells, respectively. Interestingly, in the ACT34-CMI study, a lower dose $\left(1 \times 10^{5}\right.$ cells $)$ was associated with significant and persistent improvement in angina symptoms at 2-year follow-up.
Previously published trials with refractory angina patients treated with $\mathrm{BM}$ - and $\mathrm{PB}$-derived mononuclear cells (MNC) produced promising overall results. The vast majority of studies presented a reduction of angina frequency in short- and long-term (5 years) follow-up [10, 11, 15, 17-21]. In the RE-INJECT AP trial [17], NOGA-based intramyocardial application of $100 \times 10^{6} \mathrm{BM}$ MNC was performed improving QoL and CCS class with increased myocardial perfusion during the first and second (after $4.6 \pm 2.5$ years) cell 


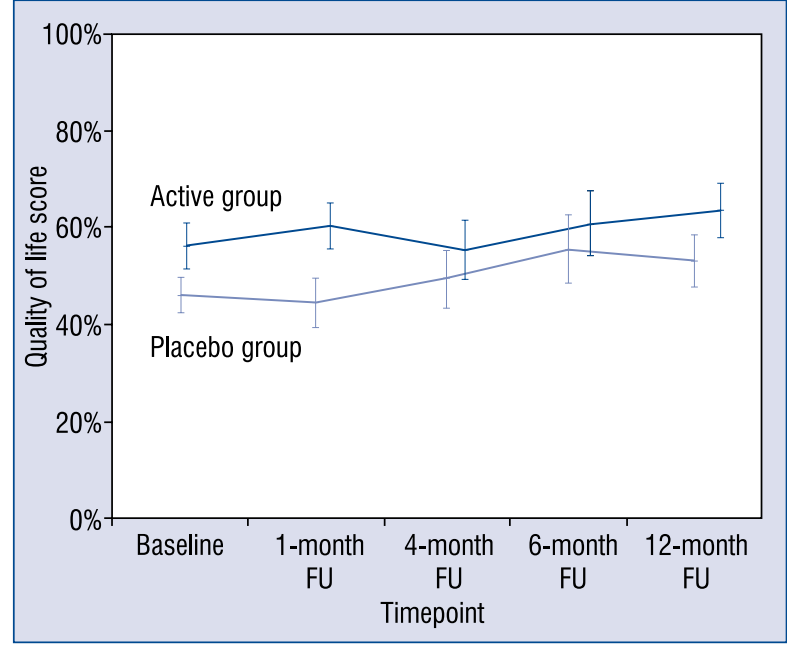

Figure 2. Quality of life scores at baseline and follow-up (FU) visits. injections. Moreover, Rodrigo et al. [18] observed similar clinical effects in patients who had had placebo injections in the past, and who had received $100 \times 10^{6}$ of MNC during the trial. Interestingly, in the REGENT-VSEL and RE-INJECT AP trials, no increase in LVEF was observed. On the contrary, patients enrolled in the PROTECT-CAD, who received low $\left(1 \times 10^{6}\right)$ or high $\left(2 \times 10^{6}\right)$ dose of MNC showed an increase of LVEF [10] with CCS reduction in the active and placebo group. Moreover, in studies by Beers et al. [19] $\left(84 \pm 20 \times 10^{6}\right.$ of bone marrow-derived mononuclear cells [BMC], trans-endocardial), Mathiasen et al. [20] $\left(21.5 \times 10^{6}\right.$ of mesenchymal stromal cells, trans-endocardial) and Lasala et al. [21] $\left(7.5 \times 10^{6}\right.$ of BMC/MNC, intracoronary) demonstrated positive impact on angina symptoms and was associated with improvement in LV function. Distinct effect of unselected

Table 2. Seattle Angina Questionnaire - quality of life score (QOLs).

\begin{tabular}{|c|c|c|c|c|}
\hline Difference in QOLs between & $\begin{array}{l}\text { Placebo group } \\
\quad(n=15)\end{array}$ & $\begin{array}{l}\text { Active group } \\
\quad(n=16)\end{array}$ & $\begin{array}{c}\text { Total } \\
(n=31)\end{array}$ & $\mathbf{P}$ \\
\hline 12M FU and baseline & $8.33(-8.33 ; 25.00)$ & $8.33(-8.33 ; 25.00)$ & $8.33(-8.33 ; 25.00)$ & 0.87 \\
\hline $6 \mathrm{M} \mathrm{FU}$ and baseline & $8.33(-8.33 ; 25.00)$ & $0.00(-8.33 ; 16.67)$ & $0.00(-8.33 ; 16.67)$ & 0.48 \\
\hline 4M FU and baseline & $0.00(-10.42 ; 10.42)$ & $0.00(-8.33 ; 0.00)$ & $0.00(-8.33 ; 8.33)$ & 0.33 \\
\hline 1M FU and baseline & $0.00(-8.33 ; 8.33)$ & $4.17(0.00 ; 8.33)$ & $0.00(0.00 ; 8.33)$ & 0.20 \\
\hline $12 \mathrm{M} \mathrm{FU}$ and $1 \mathrm{M} \mathrm{FU}$ & $8.33(-8.33 ; 33.33)$ & $0.00(-8.33 ; 16.67)$ & $4.17(-8.33 ; 18.75)$ & 0.62 \\
\hline $6 \mathrm{M} \mathrm{FU}$ and $1 \mathrm{M} \mathrm{FU}$ & $8.33(-4.17 ; 20.83)$ & $0.00(-8.33 ; 2.08)$ & $0.00(-8.33 ; 16.67)$ & 0.06 \\
\hline $4 \mathrm{M} \mathrm{FU}$ and $1 \mathrm{M} F U$ & $0.00(-2.08 ; 12.50)$ & $0.00(-16.67 ; 0.00)$ & $0.00(-8.33 ; 6.25)$ & 0.04 \\
\hline $12 \mathrm{FU}$ and $4 \mathrm{M} \mathrm{FU}$ & $-4.17(-8.33 ; 12.50)$ & $0.00(-4.17 ; 20.83)$ & $0.00(-8.33 ; 16.67)$ & 0.20 \\
\hline $6 \mathrm{M}$ FU and $4 \mathrm{M}$ FU & $0.00(-4.17 ; 20.83)$ & $0.00(0.00 ; 16.67)$ & $0.00(0.00 ; 16.67)$ & 0.72 \\
\hline $12 \mathrm{M} \mathrm{FU}$ and $6 \mathrm{M} \mathrm{FU}$ & $-8.33(-16.67 ; 4.17)$ & $0.00(-4.17 ; 8.33)$ & $0.00(-8.33 ; 8.33)$ & 0.11 \\
\hline
\end{tabular}

Data presented as median $(\mathrm{Q} 1 ; \mathrm{Q} 3) ; \mathrm{FU}$ - follow-up; $\mathrm{M}$ - months

Table 3. Seattle Angina Questionnaire - physical limitation (PL) category.

\begin{tabular}{lcccc}
\hline Difference of PL between & $\begin{array}{c}\text { Placebo group } \\
(\mathbf{n}=\mathbf{1 5})\end{array}$ & $\begin{array}{c}\text { Active group } \\
(\mathbf{n}=\mathbf{1 6})\end{array}$ & $\begin{array}{c}\text { Total } \\
(\mathbf{n}=31)\end{array}$ & $\begin{array}{c}\text { P } \\
\text { 12M FU and baseline }\end{array}$ \\
6M FU and baseline & $13.89(-8.33 ; 26.39)$ & $2.78(-2.78 ; 13.89)$ & $8.33(-2.78 ; 19.10)$ & 0.58 \\
4M FU and baseline & $8.33(-1.39 ; 16.67)$ & $5.56(-4.86 ; 11.11)$ & $5.56(-2.78 ; 14.58)$ & 0.42 \\
1M FU and baseline & $1.39(-5.56 ; 12.50)$ & $2.78(2.08 ; 14.58)$ & $2.78(-1.39 ; 14.24)$ & 0.35 \\
12M FU and 1M FU & $0.00(0.00 ; 5.42)$ & $2.78(0.00 ; 9.38)$ & $0.00(0.00 ; 8.33)$ & 0.09 \\
6M FU and 1M FU & $13.89(-9.03 ; 23.61)$ & $0.00(-8.33 ; 5.56)$ & $2.78(-8.33 ; 18.75)$ & 0.17 \\
4M FU and 1M FU & $8.33(-4.17 ; 16.67)$ & $-1.39(-11.18 ; 2.78)$ & $2.78(-8.33 ; 11.11)$ & 0.03 \\
12M FU and 4M FU & $2.78(-4.17 ; 10.56)$ & $0.00(-6.94 ; 8.33)$ & $0.00(-5.56 ; 8.33)$ & 0.50 \\
6M FU and 4M FU & $2.78(-4.17 ; 15.28)$ & $0.00(-8.33 ; 8.33)$ & $1.39(-6.25 ; 12.85)$ & 0.29 \\
12M FU and 6M FU & $5.56(-5.56 ; 14.58)$ & $0.00(-8.33 ; 2.78)$ & $0.00(-8.33 ; 8.33)$ & 0.28 \\
\hline
\end{tabular}

Data presented as median (Q1; Q3); FU — follow-up; M - months 
Table 4. Seattle Angina Questionnaire — angina stability (AS) category.

\begin{tabular}{lcccc}
\hline Difference of AS between & $\begin{array}{c}\text { Placebo group } \\
(\mathbf{n}=\mathbf{1 5})\end{array}$ & $\begin{array}{c}\text { Active group } \\
(\mathbf{n}=\mathbf{1 6})\end{array}$ & $\begin{array}{c}\text { Total } \\
(\mathbf{n}=\mathbf{3 1})\end{array}$ & $\mathbf{P}$ \\
\hline 12M FU and baseline & $0.00(-25.00 ; 50.00)$ & $0.00(0.00 ; 25.00)$ & $0.00(0.00 ; 31.25)$ & 0.93 \\
6M FU and baseline & $0.00(-12.50 ; 37.50)$ & $0.00(0.00 ; 25.00)$ & $0.00(0.00 ; 25.00)$ & 0.94 \\
4M FU and baseline & $0.00(0.00 ; 31.25)$ & $0.00(-6.25 ; 25.00)$ & $0.00(0.00 ; 25.00)$ & 0.64 \\
1M FU and baseline & $0.00(0.00 ; 25.00)$ & $0.00(0.00 ; 25.00)$ & $0.00(0.00 ; 25.00)$ & 0.91 \\
12M FU and 1M FU & $0.00(-25.00 ; 25.00)$ & $0.00(0.00 ; 25.00)$ & $0.00(-25.00 ; 25.00)$ & 0.70 \\
6M FU and 1M FU & $0.00(-37.50 ; 25.00)$ & $0.00(-6.25 ; 6.25)$ & $0.00(-25.00 ; 25.00)$ & 0.82 \\
4M FU and 1M FU & $0.00(-25.00 ; 25.00)$ & $0.00(-6.25 ; 6.25)$ & $0.00(-18.75 ; 25.00)$ & 0.85 \\
12M FU and 4M FU & $0.00(-6.25 ; 0.00)$ & $0.00(-12.50 ; 12.50)$ & $0.00(0.00 ; 0.00)$ & 0.78 \\
6M FU and 4M FU & $0.00(-25.00 ; 12.50)$ & $0.00(0.00 ; 0.00)$ & $0.00(0.00 ; 0.00)$ & 0.62 \\
12M FU and 6M FU & $0.00(0.00 ; 0.00)$ & $0.00(-25.00 ; 0.00)$ & $0.00(0.00 ; 0.00)$ & 0.33 \\
\hline
\end{tabular}

Data presented as median (Q1;Q3); FU - follow-up; $\mathrm{M}$ - months

Table 5. Seattle Angina Questionnaire - angina frequency (AF) category.

\begin{tabular}{lcccc}
\hline Difference of AF between & $\begin{array}{c}\text { Placebo group } \\
(\mathbf{n}=\mathbf{1 5})\end{array}$ & $\begin{array}{c}\text { Active group } \\
(\mathbf{n}=\mathbf{1 6})\end{array}$ & $\begin{array}{c}\text { Total } \\
(\mathbf{n}=31)\end{array}$ & $\mathbf{P}$ \\
\hline 12M FU and baseline & $10.00(0.00 ; 20.00)$ & $10.00(0.00 ; 30.00)$ & $10.00(0.00 ; 22.50)$ & 0.80 \\
6M FU and baseline & $0.00(0.00 ; 10.00)$ & $10.00(-20.00 ; 20.00)$ & $0.00(0.00 ; 20.00)$ & 0.73 \\
4M FU and baseline & $10.00(0.00 ; 10.00)$ & $0.00(-10.00 ; 20.00)$ & $0.00(0.00 ; 10.00)$ & 0.43 \\
1M FU and baseline & $0.00(0.00 ; 10.00)$ & $5.00(0.00 ; 20.00)$ & $0.00(0.00 ; 20.00)$ & 0.17 \\
12M FU and 1M FU & $10.00(0.00 ; 20.00)$ & $10.00(0.00 ; 10.00)$ & $10.00(0.00 ; 20.00)$ & 0.54 \\
6M FU and 1M FU & $0.00(0.00 ; 15.00)$ & $0.00(-20.00 ; 12.50)$ & $0.00(0.00 ; 10.00)$ & 0.37 \\
4M FU and 1M FU & $0.00(-2.50 ; 10.00)$ & $0.00(-20.00 ; 0.00)$ & $0.00(-10.00 ; 0.00)$ & 0.15 \\
12M FU and 4M FU & $0.00(-2.50 ; 12.50)$ & $10.00(0.00 ; 15.00)$ & $0.00(0.00 ; 10.00)$ & 0.20 \\
6M FU and 4M FU & $0.00(-5.00 ; 0.00)$ & $0.00(-5.00 ; 20.00)$ & $0.00(0.00 ; 0.00)$ & 0.79 \\
12M FU and 6M FU & $0.00(0.00 ; 10.00)$ & $10.00(0.00 ; 20.00)$ & $0.00(0.00 ; 10.00)$ & 0.33 \\
\hline
\end{tabular}

Data presented as median (Q1; Q3); FU — follow-up; M - months

Table 6. Seattle Angina Questionnaire - treatment satisfaction (TS) category.

\begin{tabular}{|c|c|c|c|c|}
\hline Difference in TS between & $\begin{array}{l}\text { Placebo group } \\
\text { (n=15) }\end{array}$ & $\begin{array}{l}\text { Active group } \\
\quad(n=16)\end{array}$ & $\begin{array}{c}\text { Total } \\
(n=31)\end{array}$ & $\mathbf{P}$ \\
\hline $12 \mathrm{M} \mathrm{FU}$ and baseline & $12.50(0.00 ; 18.75)$ & $0.00(0.00 ; 18.75)$ & $3.13(0.00 ; 18.75)$ & 0.97 \\
\hline $6 \mathrm{M}$ FU and baseline & $18.75(0.00 ; 25.00)$ & $0.00(0.00 ; 6.25)$ & $6.25(0.00 ; 18.75)$ & 0.10 \\
\hline 4M FU and baseline & $0.00(0.00 ; 18.75)$ & $0.00(-6.25 ; 6.25)$ & $0.00(-4.69 ; 10.94)$ & 0.17 \\
\hline $1 \mathrm{M}$ FU and baseline & $0.00(0.00 ; 6.25)$ & $3.13(0.00 ; 10.94)$ & $0.00(0.00 ; 6.25)$ & 0.43 \\
\hline $12 \mathrm{M} \mathrm{FU}$ and $1 \mathrm{M} \mathrm{FU}$ & $0.00(0.00 ; 12.50)$ & $0.00(-6.25 ; 12.50)$ & $0.00(-6.25 ; 12.50)$ & 0.60 \\
\hline $6 \mathrm{M} \mathrm{FU}$ and $1 \mathrm{M} \mathrm{FU}$ & $12.50(0.00 ; 21.88)$ & $0.00(-6.25 ; 1.56)$ & $0.00(-6.25 ; 12.50)$ & 0.05 \\
\hline $4 \mathrm{M} \mathrm{FU}$ and $1 \mathrm{M} \mathrm{FU}$ & $0.00(0.00 ; 12.50)$ & $0.00(-1.56 ; 0.00)$ & $0.00(0.00 ; 4.69)$ & 0.06 \\
\hline $12 \mathrm{M} \mathrm{FU}$ and $4 \mathrm{M} \mathrm{FU}$ & $0.00(-3.13 ; 7.81)$ & $0.00(-6.25 ; 18.75)$ & $0.00(-6.25 ; 12.50)$ & 0.58 \\
\hline $6 \mathrm{M} \mathrm{FU}$ and $4 \mathrm{M} \mathrm{FU}$ & $0.00(-6.25 ; 12.50)$ & $0.00(-6.25 ; 7.81)$ & $0.00(-6.25 ; 6.25)$ & 0.63 \\
\hline $12 \mathrm{M} \mathrm{FU}$ and $6 \mathrm{M} \mathrm{FU}$ & $0.00(-12.50 ; 6.25)$ & $0.00(-3.13 ; 18.75)$ & $0.00(-7.81 ; 12.50)$ & 0.21 \\
\hline
\end{tabular}

Data presented as median (Q1;Q3); FU - follow-up; $\mathrm{M}$ - months 
MNC on myocardium may be associated with the heterogeneity of the injected cell population.

Currently, there is no evidence to support the use of immune-selected cells (CXCR4 or CD133) over non-selected BM-MNC in patients with stable CAD or MI. In the IMPACT-CABG [22] and CARDIO133 [23] trials, CD133/CD34/CD45 triple-positive, and CD133+ cells, respectively, were injected transepicardially during a coronary artery bypass grafting procedure showing no advantage over placebo in patients with ischemic cardiomyopathy. On the contrary, Stamm et al. [24] used CD133+ cells in the same group of patients and reported improved perfusion with a significant increase in LVEF at 3-year follow-up. Interestingly, intracoronary delivery of autologous BM-derived CD133+/CD34+ cells in patients with ischemic heart diseases and a history of MI (3-6 months before enrolment), proved to have a beneficial effect on myocardium by improving perfusion and reducing the scar area [25]. Furthermore, the clinical applicability of intracoronary delivered immune-selected cells was evaluated in patients with recent MI showing improved LV function $[26,27]$. On the contrary, those results were not confirmed in the TIME trial including ST-segment elevation MI patients treated with percutaneous coronary intervention and subsequent intracoronary administration of unselected BM-MNC [28].

As presented above, the results of published studies are incoherent. Thus, it is crucial to determine the characteristics of patients who respond to cell therapy. According to individual SPECT analysis from the REGENT-VSEL and a study by Rodrigo et al. [29], patients with a higher number of abnormal perfusion segments at baseline tended to have more significant improvement after cell application. Multivariate analysis indicates that allocation to an active group increased the chance of positive response to cell treatment by 3.5 -times, and with a history of MI by 1.5-times. Moreover, diabetes was also associated with a significant response to BMC therapy [29].

The presented data suggests that application of immuno-selected CD133 cells is not optimal for angina symptom treatment in patients with chronic myocardial ischemia.

\section{Limitations of the study}

Since the study was stopped prematurely due to slow patient enrollment, it may be considered underpowered. Thus, sub-analysis results should be interpreted with caution.

\section{Conclusions}

Findings support the feasibility and safety of transendocardial injection of CD133+ cells in patients with refractory angina. The present study waslimited by a low number of patients and did not demonstrate a significant improvement in QoL or angina pectoris symptoms in patients receiving cell therapy.

\section{Acknowledgments}

The trial was an investigator-initiated study, supported by the Medical University of Silesia and funded by the European Union Structural Funds, Innovative Economy Operational Program POIG.01.01.02-00-109/09-00 and Stem Cell Therapy in Ischemic Non-treatable Cardiac Disease grant (Horizon 2020); statutory funds of the Medical University of Silesia to Dr. Wojciech Wojakowski. The authors acknowledge the kind technical help of Hanspeter Fisher, PhD (Biologics Delivery Systems).

Conflict of interest: Dr Wojciech Wojakowski received lecture honorarium from Biosense Webster Johnson\&Johnson Medical. The other authors report no conflicts.

\section{References}

1. O'Flaherty M, Huffman MD, Capewell S. Declining trends in acute myocardial infarction attack and mortality rates, celebrating progress and ensuring future success. Heart. 2015; 101(17): 1353-1354, doi: 10.1136/heartjnl-2015-307868, indexed in Pubmed: 26060117.

2. Smolina K, Wright FL, Rayner M, et al. Determinants of the decline in mortality from acute myocardial infarction in England between 2002 and 2010: linked national database study. BMJ. 2012; 344: d8059, doi: 10.1136/bmj.d8059, indexed in Pubmed: 22279113.

3. Ford ES, Ajani UA, Croft JB, et al. Explaining the decrease in U.S. deaths from coronary disease, 1980-2000. N Engl J Med. 2007; 356(23): 2388-2398, doi: 10.1056/NEJMsa053935, indexed in Pubmed: 17554120.

4. Mannheimer C, Camici P, Chester MR, et al. The problem of chronic refractory angina; report from the ESC Joint Study Group on the Treatment of Refractory Angina. Eur Heart J. 2002; 23(5): 355-370, doi: 10.1053/euhj.2001.2706, indexed in Pubmed: 11846493.

5. Montalescot G, Sechtem U, Achenbach S, et al. 2013 ESC guidelines on the management of stable coronary artery disease: the Task Force on the management of stable coronary artery disease of the European Society of Cardiology. Eur Heart J. 2013; 34(38): 2949-3003, doi: 10.1093/eurheartj/eht296, indexed in Pubmed: 23996286.

6. Mukherjee D, Comella K, Bhatt DL, et al. Clinical outcome of a cohort of patients eligible for therapeutic angiogenesis or transmyocardial revascularization. Am Heart J. 2001; 142(1): 72-74, doi: 10.1067/mhj.2001.115786, indexed in Pubmed: 11431659. 
7. Andréll P, Ekre O, Grip L, et al. Fatality, morbidity and quality of life in patients with refractory angina pectoris. Int J Cardiol. 2011; 147(3): 377-382, doi: 10.1016/j.ijcard.2009.09.538, indexed in Pubmed: 19880202.

8. Rodrigo SF, Mann I, van Ramshorst J, et al. Reduction of healthcare utilization after bone marrow cell therapy for refractory angina pectoris. Int J Cardiol. 2016; 202: 571-572, doi: 10.1016/j. ijcard.2015.09.103, indexed in Pubmed: 26447664.

9. Losordo DW, Henry TD, Davidson C, et al. Intramyocardial, Autologous CD34+ Cell Therapy for Refractory Angina. Circ Res. 2011; 109(4): 428-436, doi: 10.1161/circresaha.111.245993.

10. Tse HF, Thambar S, Kwong YL, et al. Prospective randomized trial of direct endomyocardial implantation of bone marrow cells for treatment of severe coronary artery diseases (PROTECTCAD trial). Eur Heart J. 2007; 28(24): 2998-3005, doi: 10.1093/ eurheartj/ehm485, indexed in Pubmed: 17984132.

11. van Ramshorst J, Bax JJ, Beeres SL, et al. Intramyocardial bone marrow cell injection for chronic myocardial ischemia: a randomized controlled trial. JAMA. 2009; 301(19): 1997-2004, doi: 10.1001/jama.2009.685, indexed in Pubmed: 19454638.

12. Jimenez-Quevedo P, Gonzalez-Ferrer JJ, Sabate M, et al. Selected $\mathrm{CD}_{133^{+}}$progenitor cells to promote angiogenesis in patients with refractory angina: final results of the PROGENITOR randomized trial. Circ Res. 2014; 115(11): 950-960, doi: 10.1161/ CIRCRESAHA.115.303463, indexed in Pubmed: 25231095.

13. Wojakowski W, Jadczyk T, Michalewska-Włudarczyk A, et al. Effects of Transendocardial Delivery of Bone Marrow-Derived CD133 Cells on Left Ventricle Perfusion and Function in Patients With Refractory Angina: Final Results of Randomized, DoubleBlinded, Placebo-Controlled REGENT-VSEL Trial. Circ Res. 2017; 120(4): 670-680, doi: 10.1161/CIRCRESAHA.116.309009, indexed in Pubmed: 27903568.

14. Spertus J, Winder J, Dewhurst T, et al. Development and evaluation of the Seattle Angina questionnaire: A new functional status measure for coronary artery disease. J Am Coll Cardiol. 1995; 25(2): 333-341, doi: 10.1016/0735-1097(94)00397-9.

15. Rodrigo SF, Mann I, van Ramshorst J, et al. Safety and efficacy of percutaneous intramyocardial bone marrow cell injection for chronic myocardial ischemia: Long-term results. J Interv Cardiol. 2017; 30(5): 440-447, doi: 10.1111/joic.12408, indexed in Pubmed: 28752630.

16. Povsic T, Henry T, Traverse J, et al. The RENEW Trial. Efficacy and Safety of Intramyocardial Autologous CD34(+) Cell Administration in Patients With Refractory Angina. JACC: Cardiovascular Interventions. 2016; 9(15): 1576-1585, doi: 10.1016/j.jcin.2016.05.003.

17. Mann I, Rodrigo SF, van Ramshorst J, et al. Repeated Intramyocardial Bone Marrow Cell Injection in Previously Responding Patients With Refractory Angina Again Improves Myocardial Perfusion, Anginal Complaints, and Quality of Life. Circ Cardiovasc Interv. 2015; 8(8), doi: 10.1161/CIRCINTERVENTIONS.115.002740, indexed in Pubmed: 26259770.

18. Rodrigo SF, van Ramshorst J, Beeres SL, et al. Intramyocardial injection of bone marrow mononuclear cells in chronic myocardial ischemia patients after previous placebo injection improves myocardial perfusion and anginal symptoms: an intra-patient comparison. Am Heart J. 2012; 164(5): 771-778, doi: 10.1016/j. ahj.2012.08.008, indexed in Pubmed: 23137509.

19. Beeres SL, Bax JJ, Dibbets-Schneider P, et al. Sustained effect of autologous bone marrow mononuclear cell injection in patients with refractory angina pectoris and chronic myocardial ischemia: twelve-month follow-up results. Am Heart J. 2006; 152(4): 684.e11-684.e16, doi: 10.1016/j.ahj.2006.07.018, indexed in Pubmed: 16996834.

20. Mathiasen AB, Haack-Sørensen M, Jørgensen E, et al. Autotransplantation of mesenchymal stromal cells from bone-marrow to heart in patients with severe stable coronary artery disease and refractory angina--final 3-year follow-up. Int J Cardiol. 2013; 170(2): 246-251, doi: 10.1016/j.ijcard.2013.10.079, indexed in Pubmed: 24211066.

21. Lasala GP, Silva JA, Kusnick BA, et al. Combination stem cell therapy for the treatment of medically refractory coronary ischemia: a Phase I study. Cardiovasc Revasc Med. 2011; 12(1): 29-34, doi: 10.1016/j.carrev.2010.01.001, indexed in Pubmed: 21241969.

22. Noiseux N, Mansour S, Weisel R, et al. The IMPACT-CABG trial: A multicenter, randomized clinical trial of CD133 stem cell therapy during coronary artery bypass grafting for ischemic cardiomyopathy. J Thorac Cardiovasc Surg. 2016; 152(6): 1582-1588.e2, doi: 10.1016/j.jtcvs.2016.07.067, indexed in Pubmed: 27665225.

23. Nasseri BA, Ebell W, Dandel M, et al. Autologous CD133+ bone marrow cells and bypass grafting for regeneration of ischaemic myocardium: the Cardio133 trial. Eur Heart J. 2014; 35(19): 1263-1274, doi: 10.1093/eurheartj/ehu007, indexed in Pubmed: 24497345.

24. Stamm C, Kleine HD, Choi YH, et al. Intramyocardial delivery of CD133+ bone marrow cells and coronary artery bypass grafting for chronic ischemic heart disease: safety and efficacy studies. J Thorac Cardiovasc Surg. 2007; 133(3): 717-725, doi: 10.1016/j. jtcvs.2006.08.077, indexed in Pubmed: 17320570.

25. Kurbonov U, Dustov A, Barotov A, et al. Intracoronary Infusion of Autologous CD133(+) Cells in Myocardial Infarction and Tracing by Tc99m MIBI Scintigraphy of the Heart Areas Involved in Cell Homing. Stem Cells Int. 2013; 2013: 582527, doi: 10.1155/2013/582527, indexed in Pubmed: 23983717.

26. Bartunek J, Vanderheyden M, Vandekerckhove B, et al. Intracoronary injection of CD133-positive enriched bone marrow progenitor cells promotes cardiac recovery after recent myocardial infarction: feasibility and safety. Circulation. 2005; 112(9 Suppl): I178-I183, doi: 10.1161/CIRCULATIONAHA.104.522292, indexed in Pubmed: 16159812.

27. Mansour S, Roy DC, Bouchard V, et al. One-Year Safety Analysis of the COMPARE-AMI Trial: Comparison of Intracoronary Injection of CD133 Bone Marrow Stem Cells to Placebo in Patients after Acute Myocardial Infarction and Left Ventricular Dysfunction. Bone Marrow Res. 2011; 2011: 385124, doi: 10.1155/2011/385124, indexed in Pubmed: 22046562.

28. Traverse JH, Henry TD, Pepine CJ, et al. Effect of the use and timing of bone marrow mononuclear cell delivery on left ventricular function after acute myocardial infarction: the TIME randomized trial. JAMA. 2012; 308(22): 2380-2389, doi: 10.1001/ jama.2012.28726, indexed in Pubmed: 23129008.

29. Rodrigo SF, van Ramshorst J, Mann I, et al. Predictors of response to intramyocardial bone marrow cell treatment in patients with refractory angina and chronic myocardial ischemia. Int J Cardiol. 2014; 175(3): 539-544, doi: 10.1016/j.jicard.2014.06.039, indexed in Pubmed: 25023791. 